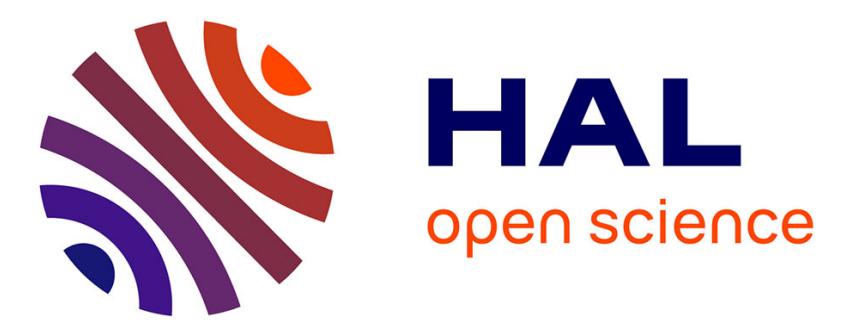

\title{
Oligomerized backbone pilin helps piliated Lactococcus lactis to withstand shear flow
}

Mickaël Castelain, Marie-Pierre Duviau, Virginie Oxaran, Philippe Schmitz, Muriel Cocaign-Bousquet, Pascal Loubière, Jean-Christophe Piard, Muriel

Mercier-Bonin

\section{To cite this version:}

Mickaël Castelain, Marie-Pierre Duviau, Virginie Oxaran, Philippe Schmitz, Muriel CocaignBousquet, et al.. Oligomerized backbone pilin helps piliated Lactococcus lactis to withstand shear flow. Biofouling, 2016, 32 (8), pp.911-923. 10.1080/08927014.2016.1213817 . hal-03031212

\section{HAL Id: hal-03031212 \\ https://hal.inrae.fr/hal-03031212}

Submitted on 13 Jan 2022

HAL is a multi-disciplinary open access archive for the deposit and dissemination of scientific research documents, whether they are published or not. The documents may come from teaching and research institutions in France or abroad, or from public or private research centers.
L'archive ouverte pluridisciplinaire HAL, est destinée au dépôt et à la diffusion de documents scientifiques de niveau recherche, publiés ou non, émanant des établissements d'enseignement et de recherche français ou étrangers, des laboratoires publics ou privés. 


\section{Oligomerized backbone pilin helps piliated Lactococcus lactis to withstand shear flow}

\section{Mickaël Castelain, Marie-Pierre Duviau, Virginie Oxaran, Philippe Schmitz, Muriel Cocaign-Bousquet, Pascal Loubière, Jean-Christophe Piard \& Muriel Mercier-Bonin}

To cite this article: Mickaël Castelain, Marie-Pierre Duviau, Virginie Oxaran, Philippe Schmitz, Muriel Cocaign-Bousquet, Pascal Loubière, Jean-Christophe Piard \& Muriel Mercier-Bonin (2016) Oligomerized backbone pilin helps piliated Lactococcus lactis to withstand shear flow, Biofouling, 32:8, 911-923, DOI: 10.1080/08927014.2016.1213817

To link to this article: http://dx.doi.org/10.1080/08927014.2016.1213817

+ View supplementary material $匚$

曲 Published online: 29 Jul 2016.

Submit your article to this journal $\pi$

Q View related articles ¿

View Crossmark data $₫$ 


\title{
Oligomerized backbone pilin helps piliated Lactococcus lactis to withstand shear flow
}

\author{
Mickaël Castelain ${ }^{\mathrm{a}}$ (D), Marie-Pierre Duviau ${ }^{\mathrm{a}}$, Virginie Oxaran ${ }^{\mathrm{b}}$, Philippe Schmitz ${ }^{\mathrm{a}}$, Muriel Cocaign-Bousquet ${ }^{\mathrm{a}}$, \\ Pascal Loubière $^{\mathrm{a}}$, Jean-Christophe Piard ${ }^{\mathrm{b}}$ (D) and Muriel Mercier-Bonin ${ }^{\mathrm{a}, \#}$ (I) \\ aLISBP, Université de Toulouse, CNRS, INRA, INSA, Toulouse, France; bMicalis Institute, INRA, AgroParisTech, Université Paris-Saclay, \\ Jouy-en-Josas, France
}

ABSTRACT

The present work focuses on the role of pili present at the cell surface of Lactococcus lactis in bacterial adhesion to abiotic (hydrophobic polystyrene) and biotic (mucin-coated polystyrene) surfaces. Native pili-displaying strains and isogenic derivatives in which pilins or sortase $C$ structural genes had been modified were used. Surface physico-chemistry, morphology and shear-flowinduced detachment of lactococcal cells were evaluated. The involvement of pili in L. lactis adhesion was clearly demonstrated, irrespective of the surface characteristics (hydrophobic/hydrophilic, presence or not of specific binding sites). The accessory pilin, PilC, and the backbone pilin, PilB, were revealed to play a major role in adhesion, provided that the PilB was present in its polymerized form. Within the population fraction that remained attached to the surface under increasing shear flow, different association behaviors were observed, showing that pili could serve as anchoring sites thus hampering the effect of shear flow on cell orientation and detachment.

\section{Introduction}

Lactococcus lactis is a major lactic acid bacterium (LAB) present in numerous ecological niches involved in the global food chain (Cavanagh et al. 2015). LAB are considered as safe organisms and have received both the GRAS (Generally Recognized As Safe) status from the FDA in the USA and the QPS (Qualified Presumption of Safety) assessment from EFSA in Europe. As LAB biota carry out crucial functions in the transformation of many agricultural products into processed food, the autochthonous LAB flora present in native products is often reinforced by the addition of bacterial starters usually consisting of cocktails of selected LAB in order to accelerate and better control fermentation processes. This practice leads to the presence of a large live LAB biota $\left(\sim 10^{9} \mathrm{cfu} \mathrm{g}^{-1}\right)$ that is ultimately ingested and delivered to the gastrointestinal tract (GIT) of humans and animals.

While L. lactis is not considered as a commensal bacterium and is only a minor component of the complex digestive microbiota (Arumugam et al. 2011; Hong et al. 2011; Lakshminarayanan et al. 2013; Mann et al. 2014), it is able, upon ingestion, to survive the harsh physico-chemical conditions of the GIT and remains metabolically active throughout its transit (Drouault et al. 1999; Daniel et al. 2013). Based on this, L. lactis has been proposed as a potent probiotic vehicle that could deliver relevant healthpromoting molecules in situ while minimizing the risk of persistence of the bacteria in the GIT. Various uses have been proposed, including the delivery of antigens in live vaccine (Dieye et al. 2003; Wells 2011), vitamins (LeBlanc et al. 2005), enzymes (Li et al. 2012), and immunomodulating effectors (Steidler et al. 2000; Motta et al. 2012).

In order to potentiate the in vivo activity of L. lactis in the GIT, it would be of great interest to identify relevant strains able to transiently colonize the gut, notably through close interactions with mucus, a protective gel-forming layer present at the surface of the intestinal mucosa. In addition to its protective role against invading bacteria, mucus is now increasingly considered as an ecological niche for commensal and probiotic bacteria (Lebeer et al. 2008) due to the presence of mucins and of their O-glycan moieties which offer nutritive sources for bacteria and/or potential ligands for bacterial adhesins. In L. lactis, specific mediators driving adhesion to mucins have been recently described

CONTACT Mickaël Castelain $\otimes$ mickael.castelain@insa-toulouse.fr

\#Toxalim, Université de Toulouse, INRA, INP-ENVT, INP-EI-Purpan, Université de Toulouse 3 Paul Sabatier, Toulouse, France

(4) The supplemental material for this paper is available online at http://dx.doi.org/10.1080/08927014.2016.1213817.

(c) 2016 Informa UK Limited, trading as Taylor \& Francis Group 
and include mucus-binding protein (MBP) and pili (Le et al. 2013). Bacterial pili are mediators of adhesion in a wide panel of bacteria, including both Gram-negative and Gram-positive bacteria (Kline et al. 2010; Danne \& Dramsi 2012). In L. lactis, it has been previously shown that sortase-dependent pili consist in three pilin proteins, namely the major PilB pilin, the polymerization of which forms the pilus shaft, a cap PilA pilin located at the tip of the pilus, and an anchoring PilC pilin located at the base of the pilus (Oxaran et al. 2012). This typical architecture, based on three pilins with dedicated localizations within the pilus, occurs in many Gram-positive bacteria although it may occasionally fluctuate as cap and anchoring pilins can also be incorporated within the pilus shaft (Reunanen et al. 2012). Those pilins are polymerized and assembled by dedicated transpeptidases, termed sortases belonging to class $\mathrm{C}$. The resulting pilus is most often anchored to the cell wall by housekeeping sortases A (Hendrickx et al. 2011).

Little is known about the molecular mechanisms governing pili-mediated adhesion of LAB to mucus. As for sortase-dependent pili SpaCBA characterized in Lactobacillus rhamnosus GG (LGG), both the SpaC cap pilin and the SpaB anchoring pilin have been initially shown to drive adhesion to human mucus in vitro (von Ossowski et al. 2010). Further studies demonstrated that $\mathrm{SpaC}$ was the major determinant of adhesion to both mucus and collagen through zipper-like adhesion involving multiple SpaC molecules distributed all along the pilus shaft, together with nanospring properties providing high adhesion forces (Kankainen et al. 2009; Tripathi et al. 2013). Interactions of a natural L. lactis strain and a pilus-deficient mutant strain with pig gastric mucin (PGM), monitored at the single-cell state using atomic force microscopy, highlighted the contribution of pili in adhesion to PGM. This was also assessed at the bacterial population level in adhesion experiments under shear flow (Le et al. 2013). Recently, single-molecule force spectroscopy has been applied to L. lactis pili using optical tweezers to characterize their nanomechanical properties (Castelain et al. 2016). It was shown that pili behave as flexible but inextensible linear polymers, which probably influence detachability under shear flow (Le et al. 2013). However, a comprehensive study on the mechanisms governing adhesion of piliated L. lactis under shear flow is still lacking. In this framework, the present work aimed at dissecting the role of pili and of their typical pilins (PilA, PilB and PilC) in L. lactis adhesion, and at unravelling the respective contributions of their structural and physico-chemical characteristics. To this end, both the morphological and the physico-chemical (hydrophobicity and surface charge) properties of $L$. lactis were first determined using a collection of strains expressing either the native pilus operon or derivative pilus operons in which pilin and/or sortase $\mathrm{C}$ structural genes had been deleted or modified. Interactions between L. lactis and abiotic/biotic surfaces were probed on the same panel of strains under well-controlled hydrodynamics (laminar flow conditions) in a shear stress flow chamber. As bacterial pili are known to mediate attachment to surfaces through hydrophobic interactions (Craig et al. 2004; Beaussart et al. 2014; Sullan et al. 2014), the involvement of these appendages in L. lactis adhesion was first evaluated to bare hydrophobic polystyrene. Then, considering previous studies pointing out the specific binding of piliated LAB eg LGG and L. lactis to mucin (Le et al. 2013; Sullan et al. 2014), further experiments using mucin-coated polystyrene as substratum were performed.

\section{Materials and methods}

\section{Bacterial strains and growth conditions}

The lactococcal strains used are listed in Table 1. All were derived from L. lactis subsp. lactis IL1403 and have been constructed previously (Oxaran et al. 2012). This IL1403 strain harbors a putative chromosomal gene cluster encoding sortase $\mathrm{C}$ and the three pilins, but no pili were detected under standard growth conditions (Oxaran et al. 2012). This operon was therefore overexpressed to yield the Pil strain that did produce full-length functional pili at the cell surface. Derivatives were constructed and analyzed. Both the Pil ${ }^{\triangle \mathrm{A}}$ strain deleted for the gene for the PilA tip pilin and the Pil ${ }^{\triangle \mathrm{A} \Delta \mathrm{C}}$ strain deleted for the genes for both the PilA tip pilin and the PilC anchoring pilin produced the backbone PilB polymerized structure (Oxaran et al. 2012). In contrast, the Pil ${ }^{\triangle B}$ strain deleted for the gene for the backbone pilin PilB and the $\mathrm{Pil}^{\text {strC*}}$ strain in which sortase $\mathrm{C}$ had been inactivated were unable to produce the pilus backbone. A schematic assembly is depicted as figure 1 in Castelain et al. (2016).

Static cultures of $L$. lactis were performed overnight at $30^{\circ} \mathrm{C}$ in $\mathrm{M} 17$ broth (Oxoid, Dardilly, France) containing $0.5 \%\left(\mathrm{w} \mathrm{v}^{-1}\right)$ glucose and $5 \mu \mathrm{g} \mathrm{ml}^{-1}$ of erythromycin (Ery). Bacterial suspensions were prepared according to the experiment to be performed (see below).

Table 1. Bacterial strains and plasmids used in this study.

\begin{tabular}{|c|c|c|}
\hline $\begin{array}{l}\text { Strain number and strain } \\
\text { designation }\end{array}$ & $\begin{array}{l}\text { Relevant characteris- } \\
\text { tic(s)* }\end{array}$ & Reference \\
\hline L. lactis VE17061, control & Wild-type strain (WT) & Oxaran et al. (2012) \\
\hline L. lactis VE17173, Pil & WT, pilA:pilB:srtC:pilC & Oxaran et al. (2012) \\
\hline L. lactis VE17148, $\mathrm{Pil}^{\Delta \mathrm{A}}$ & WT, pilB:srtC:pilC & Oxaran et al. (2012) \\
\hline L. lactis VE17183, Pil ${ }^{\triangle A \Delta C}$ & WT, pilB:srtC & Oxaran et al. (2012) \\
\hline L. lactis VE17190, Pil ${ }^{\triangle B}$ & $\triangle$ pilB, pilA:srtC:pilC & Oxaran et al. (2012) \\
\hline L. lactis VE17191, Pil $\left.\right|^{\mathrm{Srtc}}$ & $\Delta s r t C$, pilA:pilB:pilC & Oxaran et al. (2012) \\
\hline
\end{tabular}

"The host strain and the over-expressed pil operon derivatives are indicated; the pil operon and the topology of the predicted gene products are shown in figure 1 in Castelain et al. (2016). Genes yhgD, yhgE, yhhA, and yhhB, whose functions have been characterized (Oxaran et al. 2012), are hereafter termed pilA, pilB, srtC, and pilC, respectively. SrtC* designates sortase $C$ whose active site has been inactivated. 


\section{Physico-chemical properties of bacteria and pili}

\section{Hydrophobic character of the bacterial cell surface}

The microbial adhesion to solvents (MATS) method (Bellon-Fontaine et al. 1996), restricted here to hexadecane (an apolar alkane), was used to assess the hydrophobic character of the $L$. lactis cell surface. Bacteria were harvested during the stationary growth phase (cell density $\sim 2.5 \times 10^{9} \mathrm{cfu} \mathrm{ml}^{-1}$, corresponding to an optical density of 2.5 at a wavelength of $\left.600 \mathrm{~nm}\left(\mathrm{OD}_{600}\right)\right)$ by centrifugation $(1,000 \mathrm{~g}, 10 \mathrm{~min}$, room temperature), washed with $150 \mathrm{mM} \mathrm{NaCl}$ and resuspended in the same solution at a final cell density of $\sim 5.0 \times 10^{8} \mathrm{cfu} \mathrm{ml}^{-1}\left(\mathrm{OD}_{600}\right.$ of 0.5$)$. The bacterial suspension $(2.4 \mathrm{ml})$ was gently homogenized for $60 \mathrm{~s}$ with $0.4 \mathrm{ml}$ of hexadecane (Sigma-Aldrich, SaintQuentin Fallavier, France). The mixture was allowed to stand for $15 \mathrm{~min}$ in order to ensure complete phase separation and a sample $(1 \mathrm{ml})$ was carefully removed from the aqueous phase for OD measurement at $600 \mathrm{~nm}$. The microbial adhesion to hexadecane was calculated using the following equation:

$$
\text { Adhesion }=\left(1-\mathrm{OD} / \mathrm{OD}_{0}\right) \times 100
$$

where $\mathrm{OD}_{0}$ is the initial optical density at $600 \mathrm{~nm}$ of the bacterial suspension before mixing with the solvent, and $\mathrm{OD}$ is the final absorbance at $600 \mathrm{~nm}$ after mixing and phase separation. Experiments were performed in triplicate using three independent bacterial cultures.

\section{Pili hydrophobicity via hydrophobic cluster analysis of PilB}

To predict the potential organization of the secondary structure of the PilB backbone pilin into hydrophobic clusters, the hydrophobic cluster analysis (HCA) (Woodcock et al. 1992; Callebaut et al. 1997) consisting of using a 2-D helical representation of the sequence combined with the protein secondary structures statistically centered on hydrophobic clusters was performed. This method affords a robust way of predicting the presence of hydrophobic patches. To obtain the mature sequence of PilB to be analyzed, the precursor sequence of PilB (accession number NP_266914.1) was deleted from both its predicted $\mathrm{N}$-terminal signal sequence as determined using the SignalP server (http://www.cbs.dtu.dk/services/ SignalP/) and its C-terminal fragment located at the $\mathrm{C}$-terminus of the threonine residue within the LPxTG motif processed by sortases.

\section{Bacterial cell surface electrical charge}

The global electrical properties of the L. lactis cell surface were assessed by measuring bacterial electrophoretic mobility which corresponds to the velocity of suspended cells exposed to an electric field. Bacteria were harvested during the stationary growth phase (cell density $~ 2.5 \times 10^{9}$ cfu ml $\mathrm{m}^{-1}, \mathrm{OD}_{600}$ of 2.5$)$ by centrifugation $(1,000 \mathrm{~g}, 10 \mathrm{~min}$, room temperature), washed with $1 \mathrm{mM} \mathrm{KNO}_{3} \mathrm{pH}=7.4$ and resuspended in the same solution at a final cell concentration of $\sim 3.0 \times 10^{8} \mathrm{cfu} \mathrm{ml}^{-1}\left(\mathrm{OD}_{600}\right.$ of 0.3$)$. The $\mathrm{pH}$ of the bacterial suspension was adjusted to values of 3,5 and 7 using either nitric acid $\left(\mathrm{HNO}_{3}\right.$, Sigma-Aldrich) or potassium hydroxide ( $\mathrm{KOH}$, Sigma-Aldrich). The electrophoretic mobility was measured using an automated laser zetameter (Zetasizer NanoZS, Malvern Instruments SARL, Orsay, France) under a 50-V electric field and was expressed in $\mathrm{m}^{2} \mathrm{~s}^{-1} \mathrm{~V}$. Experiments were conducted with at least three independent bacterial cultures.

\section{Morphological analysis of L. lactis cells}

The morphology of $L$. lactis cells was analyzed using an automated particle characterization system (Morphologi G3S, Malvern Instruments SARL, Orsay, France, SN: MAL1033756, software Morphologi v 8.11). The device works as a microscope equipped with a $20 \times$ magnification upright objective and a camera (Nikon CFI60, Nikon France SA, Champigny-sur-Marne, France). Bacterial cells were harvested during the stationary growth phase (cell density $\sim 2.5 \times 10^{9} \mathrm{cfu} \mathrm{ml}^{-1}, \mathrm{OD}_{600} 2.5$ ) by centrifugation $(1,000 \mathrm{~g}, 10 \mathrm{~min}$, room temperature) washed with phosphate buffered saline (PBS) and resuspended in the same solution at a final cell concentration of $\sim 1.2 \times 10^{9} \mathrm{cfu} \mathrm{ml}^{-1}$ $\left(\mathrm{OD}_{600} 1.2\right)$. Typically, the bacterial suspensions, containing 5,000-10,000 cells $\mathrm{mm}^{-2}$, were observed between cover glass and slide under dark-field illumination conditions. The images were filtered and analyzed to determine the number of particles and their geometric properties.

\section{Preparation of the PGM-coated polystyrene surfaces}

The pig gastric mucin (PGM) was purchased as a lyophilized powder (Sigma-Aldrich M1778, partially purified type-III mucin from porcine stomach). PGM was directly dissolved in $\mathrm{PBS}$ at $\mathrm{pH} 7.5$ at a final concentration of $10 \mathrm{mg} \mathrm{ml}^{-1}$. The solutions were prepared just before use.

Polystyrene was used as the substratum in the form of rectangular coupons $\left(25.2 \times 6.3 \times 2.0 \mathrm{~mm}^{3}\right)$ for flow chamber experiments. Coupons were immersed in $2 \%$ (v/v) RBS 25 liquid detergent (Traitements Chimiques de Surfaces, Frelinghien, France) at $50^{\circ} \mathrm{C}$ for $15 \mathrm{~min}$, rinsed in five successive baths of tap water at $50^{\circ} \mathrm{C}$ and five successive baths of tap water at room temperature, rinsed again with copious amounts of MilliQ-grade water $\left(50^{\circ} \mathrm{C}\right.$ and room temperature) and finally air-dried for $15 \mathrm{~min}$ under a vertical flow hood (Cytosafe 2000, Faster, Italy). Surfaces were either used immediately or stored in a desiccator at room temperature until use. 
PGM adsorption onto polystyrene was performed as previously described (Le et al. 2013). Briefly, polystyrene coupons, prepared according to the above procedure, were exposed overnight to a $10 \mathrm{mg} \mathrm{ml}^{-1} \mathrm{PGM}$ solution in PBS $\mathrm{pH} 7.5$ at $4^{\circ} \mathrm{C}$, under gentle agitation. After incubation, the surfaces were copiously rinsed to remove loosely bound material using PBS and MilliQ-grade water, successively and were finally air-dried under a vertical flow hood (Cytosafe 2000, Faster, Italy). The characteristics of the PGM layer after adsorption onto rectangular polystyrene coupons have been described elsewhere (Le et al. 2013).

\section{Detachment of L. lactis cells from bare and mucin- coated polystyrene in a shear stress flow chamber}

For each L. lactis strain under study, shear-flow-induceddetachment experiments were performed in a rectangular flow channel $12 \mathrm{~mm}$ wide, $25.2 \mathrm{~mm}$ long and $200 \mu \mathrm{m}$ thick, as previously described (Le et al. 2013). In brief, the flow chamber and all tubes were filled with PBS and special care was taken to remove air bubbles from the system. Bacterial cells were harvested during the stationary growth phase (cell density $\sim 2.5 \times 10^{9} \mathrm{cfu} \mathrm{ml}^{-1}, \mathrm{OD}_{600} 2.5$ ) by centrifugation $(1,000 \mathrm{~g}, 10 \mathrm{~min}$, room temperature), washed with PBS and resuspended in the same solution at a final cell concentration of $\sim 3.0 \times 10^{8} \mathrm{cfu} \mathrm{ml}^{-1}\left(\mathrm{OD}_{600}\right.$ 0.3). The bacterial suspension (volume $700 \mu \mathrm{l}$ ) was then slowly injected into the flow chamber and allowed to attach to the polystyrene, with or without the PGM coating, for $3 \mathrm{~h}$ under 'static' conditions. Images, collected using the reflection mode of an upright optical microscope (Nikon Eclipse LV100) equipped with a $40 \times$ ultra-long working distance objective, were recorded by a camera (digital SIGHT DS-2MBW, Nikon) and the NIS-Elements F3.0 video acquisition software (Nikon). The field of view was $176 \mu \mathrm{m}$ by $132 \mu \mathrm{m}$ with a resolution of $0.11 \mu \mathrm{m}$ pixel $^{-1}$.

After the 3-h adhesion step, rinsing with PBS was carried out at a low flow rate of $0.001 \mathrm{ml} \mathrm{s}^{-1}$ in order to stabilize the system and remove loosely adhering bacteria. The surface covered by the remaining attached cells was thereafter referred to as $\mathrm{A}_{0}$. It should be noted that the $\mathrm{A}_{0}$ value was in the range $1 \%-3 \%$ of the total surface area, so interactions between neighboring bacteria were considered to be minimal. Laminar flow of PBS was then imposed, with a stepwise increase in the flow rate (maximum value of $6.7 \mathrm{ml} \mathrm{s}^{-1}$ ) and a 3-min step duration. Flow rates ranging from 0.001 to $0.3 \mathrm{ml} \mathrm{s}^{-1}$ were generated by gravity by simply controlling the height of a constant head vessel located upstream of the chamber. Higher flow rates were obtained using a gear pump (Ismatec, Fisher Bioblock Scientific, Illkirch-Graffenstaden, France). The wall shear stress $\tau_{W}$ was given by:

$$
\tau_{W}=\frac{3 \mu Q}{4 h^{2} l},
$$

where $\mu$ is the fluid dynamic viscosity (Pa s), $Q\left(\mathrm{~m}^{3} \mathrm{~s}^{-1}\right)$ is the flow rate, and $l$ and $h$ are the channel half-width and half-thickness $(\mathrm{m})$, respectively. The applied wall shear stress was in the range of $0-85 \mathrm{~Pa}$.

At the end of each wall shear stress step, the percentage of the surface covered by attached bacteria (A) was estimated with the free software Macbiophotonics ImageJ (www.macbiophotonics.ca) and the MATLAB software (MathWorks Inc., Austin, TX, USA). The detachment profile, representing the ratio $\mathrm{A} / \mathrm{A}_{0}$ as a function of $\tau_{W}$, was plotted. Experiments were performed at least in triplicate for each strain using different PGM-coated coupons and independently grown cultures.

\section{Position and orientation of adhering bacteria using image analysis}

For each strain under study, images were processed to track typical displacement of some individual bacterial cells under the shear flow (lying flat, sliding, rotating, or stationary). Image analysis was also carried out on each image to determine the position and orientation of each bacterium through the determination of the a value, $a$ being defined as the angle between the cell body and the main flow direction. Bacterial cells were classified in nine classes according to their initial $\alpha$ value in the range $0-90^{\circ}$ (steps of $10^{\circ}$ ). The evolution of these classes with increasing wall shear stress was determined in relation to the L. lactis detachability and the strain characteristics, in particular the presence of pili.

\section{Statistical analyses}

The electrophoretic mobility, MATS and morphometric data of L. lactis bacterial cells were analyzed using analysis of variance (one-way ANOVA), followed by Tukey's post hoc test using OriginLab 2016 software (OriginLab Co., Northampton, MA, USA). Cell detachment profiles from bare and mucin-coated polystyrene surfaces were analyzed using two-way ANOVA with OriginLab 2016. Significant differences were displayed when $p<0.05\left(^{*}\right)$ and $p<0.001\left(^{* *}\right)$.

\section{Results}

Morphological and cell surface properties of $\mathrm{L}$. lactis strains

Non-specific interactions between two surfaces are known to be driven among other things by both electrostatic and hydrophobic contributions (van Oss 1994). In addition, the hydrodynamic force applied to adhering cells, ie the drag force, is intimately related to cell size, 
Table 2. Characterization of the cell surface properties (percentage of bacteria bound to hexadecane used in the MATS method and the electrophoretic mobility [EM in $\left.\mathrm{m}^{2} \mathrm{~s}^{-1} \mathrm{~V}^{-1}\right]$ ) and morphological parameters (apparent width [ $\left.\mu \mathrm{m}\right]$ of the cells or chains and number of cells per chain) for all the strains of $L$. lactis under study.

\begin{tabular}{|c|c|c|c|c|c|c|}
\hline & Control & Pil & $\mathrm{Pil}^{\Delta \mathrm{A}}$ & $\mathrm{Pil}^{\triangle \mathrm{A} \Delta \mathrm{C}}$ & $\mathrm{Pil}^{\Delta \mathrm{B}}$ & $\mathrm{Pil}^{\mathrm{SrtC}}{ }^{*}$ \\
\hline Affinity to hexadecane [\%] & $3.9 \pm 2.8$ & $17.0 \pm 3.4$ & $10.6 \pm 2.1$ & $3.8 \pm 3.6$ & $1.5 \pm 1.9$ & $37.2 \pm 3.8$ \\
\hline \multicolumn{7}{|c|}{ Electrophoretic mobility $\left(\mathrm{m}^{2} \mathrm{~s}^{-1} \mathrm{~V}^{-1}\right)$} \\
\hline $\begin{array}{l}\mathrm{pH}=3 \\
\mathrm{pH}=5 \\
\mathrm{pH}=7 \\
\text { Apparent width }[\mu \mathrm{m}] \\
\text { Number of cells per chain }\end{array}$ & $\begin{array}{r}-1.2 \pm 0.2 \\
-2.5 \pm 0.1 \\
-2.1 \pm 0.1 \\
1.0 \pm 0.3 \\
2.5 \pm 1.3\end{array}$ & $\begin{array}{r}-0.6 \pm 0.1 \\
-2.1 \pm 0.1 \\
-2.4 \pm 0.1 \\
1.0 \pm 0.2 \\
3.6 \pm 1.2\end{array}$ & $\begin{array}{r}-0.5 \pm 0.3 \\
-2.1 \pm 0.1 \\
-2.3 \pm 0.1 \\
1.1 \pm 0.2 \\
3.0 \pm 1.6\end{array}$ & $\begin{array}{r}-0.4 \pm 0.6 \\
-2.0 \pm 0.1 \\
-2.0 \pm 0.1 \\
1.1 \pm 0.2 \\
2.5 \pm 1.0\end{array}$ & $\begin{array}{r}-0.3 \pm 0.3 \\
-2.0 \pm 0.1 \\
-2.1 \pm 0.1 \\
1.0 \pm 0.2 \\
2.8 \pm 1.1\end{array}$ & $\begin{array}{r}-1.6 \pm 0.2 \\
-2.9 \pm 0.1 \\
-2.8 \pm 0.1 \\
1.0 \pm 0.3 \\
3.2 \pm 1.4\end{array}$ \\
\hline
\end{tabular}

For the percentage of cell affinity to hexadecane and EM, the data represent the mean of nine values \pm SDs $(n=9$, three independent experiments, each performed in triplicate). For the morphometric analysis, the data correspond to mean values \pm SDs.

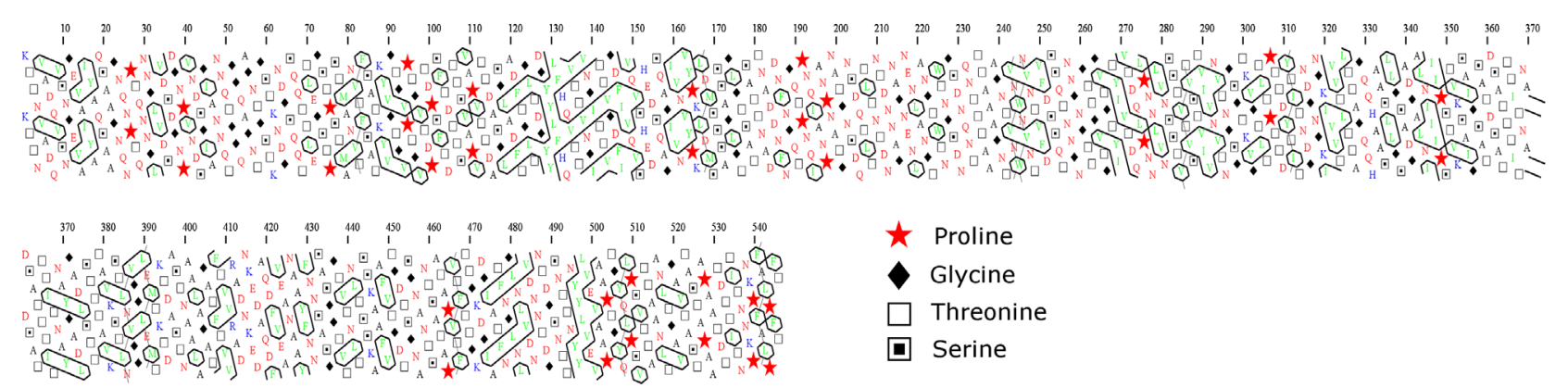

Figure 1. Hydrophobic cluster analysis plot from the PilB backbone pilin sequence represented in a 2-D helix statistically centered on hydrophobic clusters. Green amino acids are the V, I, L, F, M, W, and Y. Most hydrophobic residues clustered into patches.

shape and morphology. In this regard and in order to evaluate the contribution of pili on the detachability of adhering cells, thorough analyses of the morphology and the cell surface properties of L. lactis (hydrophobicity and electronegativity) were performed. The strains investigated included the native pili-displaying strain (Pil), the control non-piliated strain and all derivatives in which pilins or sortase $\mathrm{C}$ structural genes had been modified ( $\mathrm{Pil}^{\triangle \mathrm{A}}, \mathrm{Pil}^{\triangle \mathrm{AAC}}, \mathrm{Pil}^{\triangle \mathrm{B}}$ and $\mathrm{Pil}^{\mathrm{StC} \mathrm{C}^{*}}$ ), as illustrated in Castelain et al. (2016).

\section{Physico-chemical properties of the bacterial cell surface}

The cell surface hydrophobicity levels expressed as a percentage of adhesion to hexadecane of $\mathrm{Pil}^{\triangle \mathrm{A} \Delta \mathrm{C}}, \mathrm{Pil}^{\triangle \mathrm{B}}$ and control strains did not show significant variation $(p>0.5)$, suggesting hydrophobic characters very close to those of pili-deficient strains (note that $\mathrm{Pil}^{\triangle \mathrm{AAC}}$ strain is able to produce the pilus backbone but most of which is released into the surrounding medium (Castelain et al. 2016)) (Table 2). A second group (Pil and $\mathrm{Pil}^{\triangle \mathrm{A}}$ ) showed moderate affinity to hexadecane (10-17\%). Finally, the $\mathrm{Pil}^{\mathrm{SrtC}}{ }^{*}$ strain which displays the three pilins as monomers anchored at the bacterial surface showed a higher affinity to hexadecane (37\%) than other strains $(p<0.001)$, suggesting a more elevated, albeit moderately, hydrophobic character. Taken together, these results suggest that PilB, especially when it is anchored as monomers to the cell surface, conferred an increased hydrophobic character to L. lactis.

PilB-mediated hydrophobic properties were further investigated by performing a hydrophobic cluster analysis from the pilin sequence. Figure 1 shows an HCA plot obtained with the PilB sequence. The prediction identified the presence of numerous hydrophobic clusters presumably involved in $\alpha$-helices and $\beta$-strands (Callebaut et al. 1997). Such results are consistent with the previously depicted hydrophobicity of many bacterial pili (Craig et al. 2004).

The electrophoretic mobility of the L. lactis strains investigated was measured at three different $\mathrm{pH}$ values (3, 5 and 7). The results indicated that all strains were strongly negatively charged at $\mathrm{pH}$ values between 5 and 7 , while a strong reduction in the cell electrophoretic mobility occurred at $\mathrm{pH} 3$ (Table 2), in agreement with previous findings in L. lactis (Giaouris et al. 2009). Whatever the $\mathrm{pH}$, the Pil and $\mathrm{Pil}^{\Delta \cdot}$ strains producing cell wall anchored PilB polymers exhibited a similar negative charge $(p<$ $0.05)$. The charge of the $\mathrm{Pil}^{\triangle \mathrm{A} \Delta \mathrm{C}}$ strain was similar to those of Pil, $\mathrm{Pil}^{\Delta \mathrm{s}}, \mathrm{Pil}^{\Delta \mathrm{B}}$ stains at $\mathrm{pH}=3$ and $5(p>0.05)$ but differed from that of the control strain $(p<0.001)$. The $\mathrm{Pil}^{\mathrm{SrCC}^{*}}$ strain showed a charge that was similar to that of the control $(p>0.05)$ at $\mathrm{pH}=7$ and significantly more negative $(p<0.001)$ than those of other strains at $\mathrm{pH}=5$ and 7. 


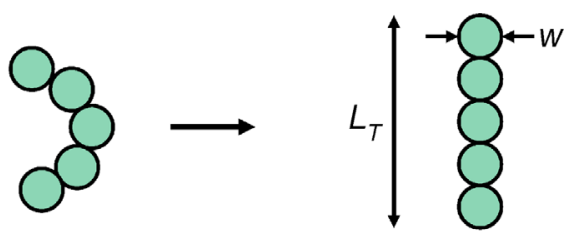

(A)
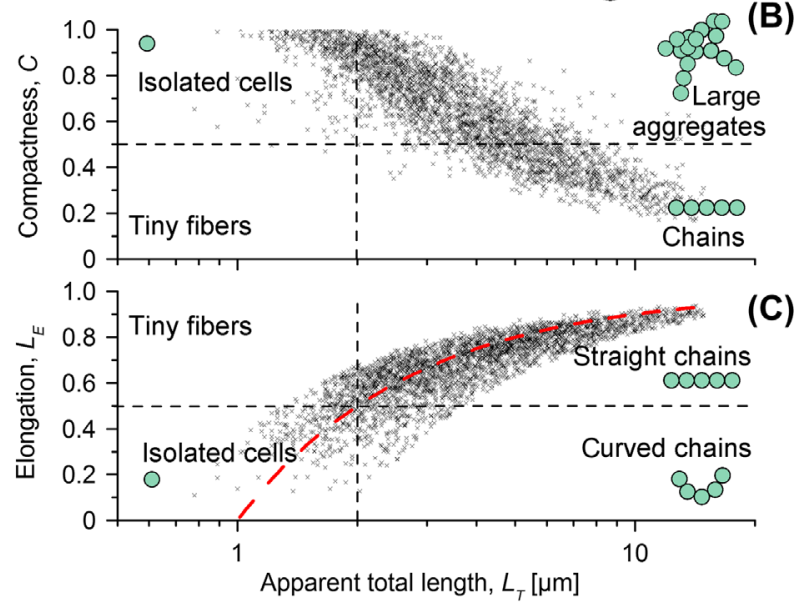

(C)
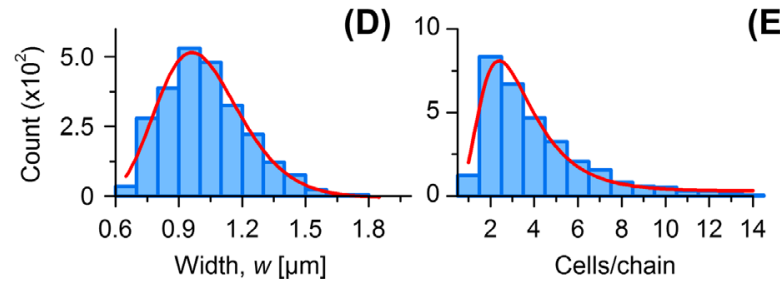

Figure 2. Morphological analysis of $L$. lactis cells. The example of the Pil strain is shown. (A) scheme representing detection of $L$. lactis five-cell chains described by their width $w$ and length $L_{T}$ (B) compactness $C$ and $(C)$ elongation $L_{E^{\prime}}$ both described by Equation 2 , vs apparent total length $L_{T}(\mu \mathrm{m})$. Typical morphology of each zone is described by a scheme or a legend. Elongation, which describes the straightness of chain, was fitted with the rational function of Equation 2 (red dashed line). (D) Distribution of the width $w(\mu \mathrm{m})$ fitted with lognormal function (red solid line). (E) Distribution of number of cells per bacterial chain fitted with lognormal function (red solid line). The fit values are reported in Table 2.

\section{Morphological properties of $\mathrm{L}$. lactis}

Because of the effect of size in the detachability of microorganisms under shear flow (Mercier-Bonin et al. 2011), a morphometric analysis was performed on thousands of $L$. lactis cells for all the strains under study. The morpho-granulometer is able to detect fiber-like particles, such as bacterial chains, and to extract the parameters width, $w$, and total length, $L_{T}$, as if the bacterial chains were totally straight (see scheme in Figure 2A). Figure 2B and $\mathrm{C}$ describe the compactness, $C$, and elongation, $L_{E}$, as a function of the total length, defined as follows:

$$
\begin{aligned}
& C=\frac{4 \pi \text { Area }}{\text { Perimeter }^{2}}, \\
& L_{E}=1-\frac{w}{L_{T}},
\end{aligned}
$$

$L_{E}$ describes the length of the major axis of a nonspherical particle and $C$ is a high-sensitive value of the circularity obtained from the area and the perimeter of the detected particle.

For all the strains under study, large numbers of small (tiny fibers with $\mathrm{C} \approx 0.2$ and $\mathrm{L}_{\mathrm{T}}<0.5$ ) and large (large aggregates) particles were detected. Tiny fibers were eliminated since they are not representative of lactococci. The data were then filtered according to the area distribution and aspect ratio, taking away small particles and large aggregates that did not reflect the morphology of the population but were only artifacts from sample preparation. The population detected displayed a morphology from circular cells to elongated cell aggregates in panels $\mathrm{B}$ and C. In panel B, circular cells reflected isolated cells $\left(\mathrm{L}_{T} \sim 1 \mu \mathrm{m}, \mathrm{C} \sim 1\right)$ and elongated cells related to chains $\left(\mathrm{L}_{T}>2 \mu \mathrm{m}, \mathrm{C}=0.2\right)$. Analysis of the morphology of the population, as retrieved in panel $\mathrm{C}$, showed that chains appeared to be rather straight $\left(\mathrm{L}_{E}>0.5\right)$. The distribution of $w$ is presented in Figure 2D and reported in Table 2. For all strains, the width was about $1 \mu \mathrm{m}$, which is consistent with the expected value for the diameter of lactococci. The apparent total length was normalized by $w$ to provide the number of cells per chain (Figure 2E and Table 2), assuming cells to be spherical. The width and number of cells per chain of all the strains tested did not differ significantly.

\section{Role of pili and their typical pilins on shear flow induced detachment of $\mathrm{L}$. lactis bacterial cells from bare and mucin-coated surfaces}

To assess whether, and if so how, the presence of pili on the cell surface of $L$. lactis influenced its capacity to adhere to abiotic (hydrophobic polystyrene) and biotic (mucin-coated polystyrene) surfaces, shear-flow-induced detachment of lactococcal cells was evaluated for the pili-displaying strain Pil and its derivatives. The corresponding detachment profiles are displayed in Figure 3.

Upon shear stress increase, L. lactis Pil and $\mathrm{Pil}^{\Delta \mathrm{P}}$ remained strongly attached to bare polystyrene while substantial detachment of L. lactis $\mathrm{Pil}^{\Delta \mathrm{B}}, \mathrm{Pi}^{\Delta{ }^{\Delta \mathrm{Pi}}}, \mathrm{Pi}^{\mathrm{SrtC}}{ }^{*}$ and the control strain from the support was observed, especially when the shear stress was within the $0-10 \mathrm{~Pa}$ range (Figure 3A). Above this threshold, detachment tended to level off and, at the end of the experiment, ie at $85 \mathrm{~Pa}$ wall shear stress, $\sim 90 \%$ of cells had detached from the bare substratum, except for the Pil and $\mathrm{Pil}^{\Delta}$ strains for which a maximum of only $25 \%$ had detached (Figure $3 \mathrm{~A}$ ).

When mucin was adsorbed onto polystyrene, the general features of the detachment profiles showed a similar tendency to those observed with the native hydrophobic surface, ie one group of muco-adhesive strains (Pil and $\mathrm{Pil}^{\Delta \mathrm{o}}$ ) and another group of weaker muco-adhesive strains 


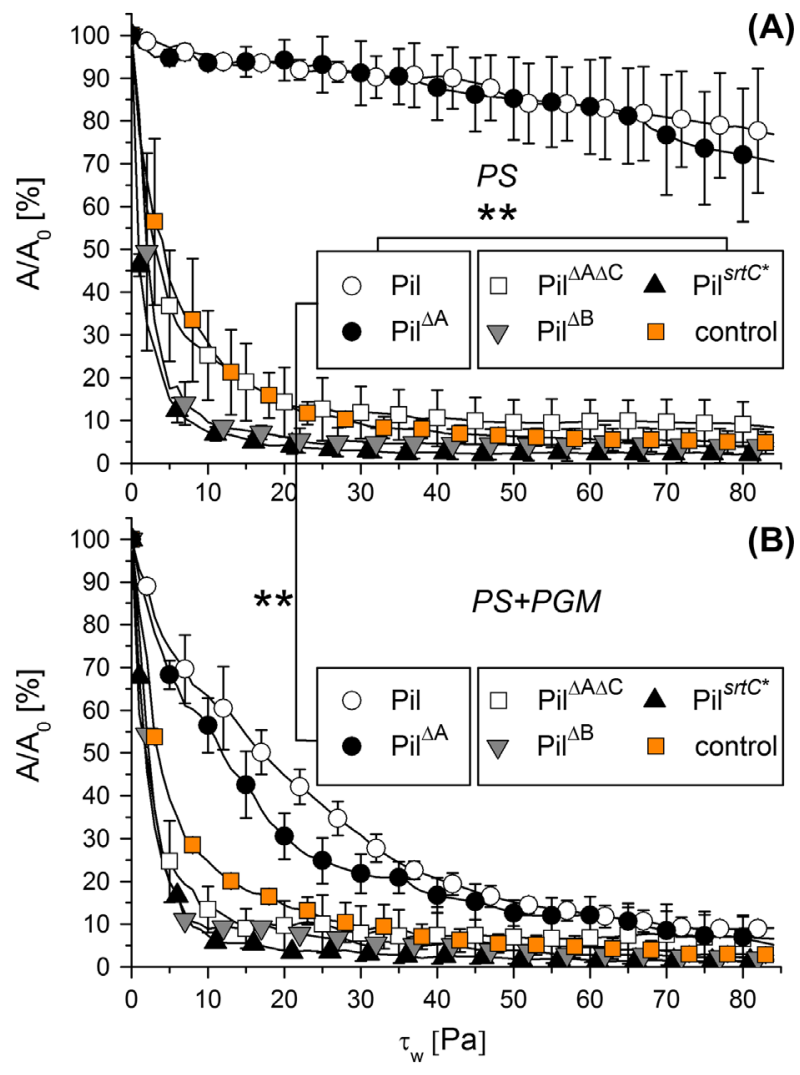

Figure 3. Shear-flow induced detachment profiles of the L. lactis strains displaying a native or truncated form of pili. Bacterial cells were attached to (A) bare (PS) and (B) mucin-coated polystyrene (PS + PGM) in PBS; control (orange square); Pil (open circle); $\mathrm{Pil}^{\triangle \mathrm{A}}$ (black circle); $\mathrm{Pil}^{\triangle A \triangle C}$ (open square); $\mathrm{Pi}^{\triangle \mathrm{B}}$ (gray inverted triangle); $\mathrm{Pil}^{\text {Srtc* }}$ (black triangle). The results shown are the average values and SDs over at least three different coupons and independently grown cultures. Two-way analysis of variance followed by a Tukey's post hoc test with significance level $p<0.001\left(^{* *}\right)$.

$\left(\mathrm{Pil}^{\Delta \mathrm{B}}, \mathrm{Pil}^{\triangle \mathrm{Pi}}, \mathrm{Pil}^{\mathrm{SrtC}}{ }^{*}\right.$ and the control) appeared (Figure 3B). The $\mathrm{A} / \mathrm{A}_{0}$ ratio of the group displaying weak adhesion indicated similar adhesion to bare and mucin-coated polystyrene surfaces. The pili-displaying strains (Pil and $\mathrm{Pil}^{\Delta \mathrm{a}}$ ) exhibited significant higher adhesion properties to both surfaces than the other group $(p<0.001)$. Nevertheless, from a general point of view, $\mathrm{Pil}$ and $\mathrm{Pil}^{\Delta}$. adhesion to mucin was much lower than that to bare polystyrene $(p<$ 0.001 ), and differed only slightly from that of the weak adhesion group $(p<0.1)$ (Figure $3 \mathrm{~B})$.

Collectively, these results show that L. lactis Pil and $\mathrm{Pil}^{\triangle \mathrm{A}}$ were the most adhesive strains, thereby suggesting the involvement of pili in adhesion of L. lactis to bare and mucin-coated polystyrene, irrespective of their characteristics (hydrophobic/hydrophilic, presence or absence of specific binding sites). Interestingly, the cap pilin PilA was dispensable for adhesion as its absence within the pilus did not significantly impact the adhesion profiles $(p=1)$. In contrast, the PilC accessory pilin and the PilB shaft pilin appeared to play key roles in adhesion, provided that the latter was present in its polymerized form, as the presence of an inactive sortase $\mathrm{C}\left(\mathrm{Pil}^{\mathrm{SrtC}^{*}}\right)$ in the pilus operon substantially reduced adhesion (Figure 3 ). In contrast with studies reported for L. rhamnosus GG and the L. lactis vegetal isolate TIL448 (Le et al. 2013; Tripathi et al. 2013), no strong interactions between pili and mucin were observed to occur here.

\section{Influence of shear flow on the surface attachment behavior of $\mathrm{L}$. lactis}

Images acquired during the course of the experiment in the flow chamber were processed for all strains in order to analyze the behavior of individual chain-forming L. lactis bacterial cells attached to the bare or mucincoated surface.

Different attachment behaviors exhibited by the cell population were observed. Figure 4 displays an example of two successive images of $\mathrm{Pil}^{\mathrm{SrtC}^{*}}$ cells, attached to bare polystyrene, before and after the washing step (wall shear stress of $\sim 0.01 \mathrm{~Pa}$ ) and the patterns obtained with the other strains on bare and mucin-coated surfaces can be found in Figure S1 in the Supplemental material. A significant heterogeneity within the population could be observed, in terms of both position and orientation compared to the flow direction (horizontal, from right to left) and to the solid surface (standing perpendicular to the surface or lying on it). Individual bacterial cells were then considered (Figure 4). First, as indicated by the white dashed circles, some cells appeared to remain stationary as they did not exhibit any observable movement under the applied shear stress. Other cells such as those highlighted by the white solid circle were positioned perpendicularly to the substratum. This cell orientation was readily detected as a spherical cellular shape since the bacterium was observed 'on end'. Under medium flow, these cells gradually tended to lie flat on the surface. Some other cells (indicated by the black arrow in the black dashed circle) appeared to be attached to the surface but moved in the direction of flow (sliding) when the wall shear stress was increased. Finally, as exemplified in Figure 4 by the white four-arc circles, rotating bacteria were also detected. They appeared to be attached to the solid surface by a single anchoring point and spun counterclockwise around that point under increasing wall shear stress until alignment with the flow was reached. These different types of L. lactis/surface attachment behavior (stationary, lying flat, sliding, rotating cells) were also observed with the other strains and with the mucin-coated surface (Figure S1). The main tendency 

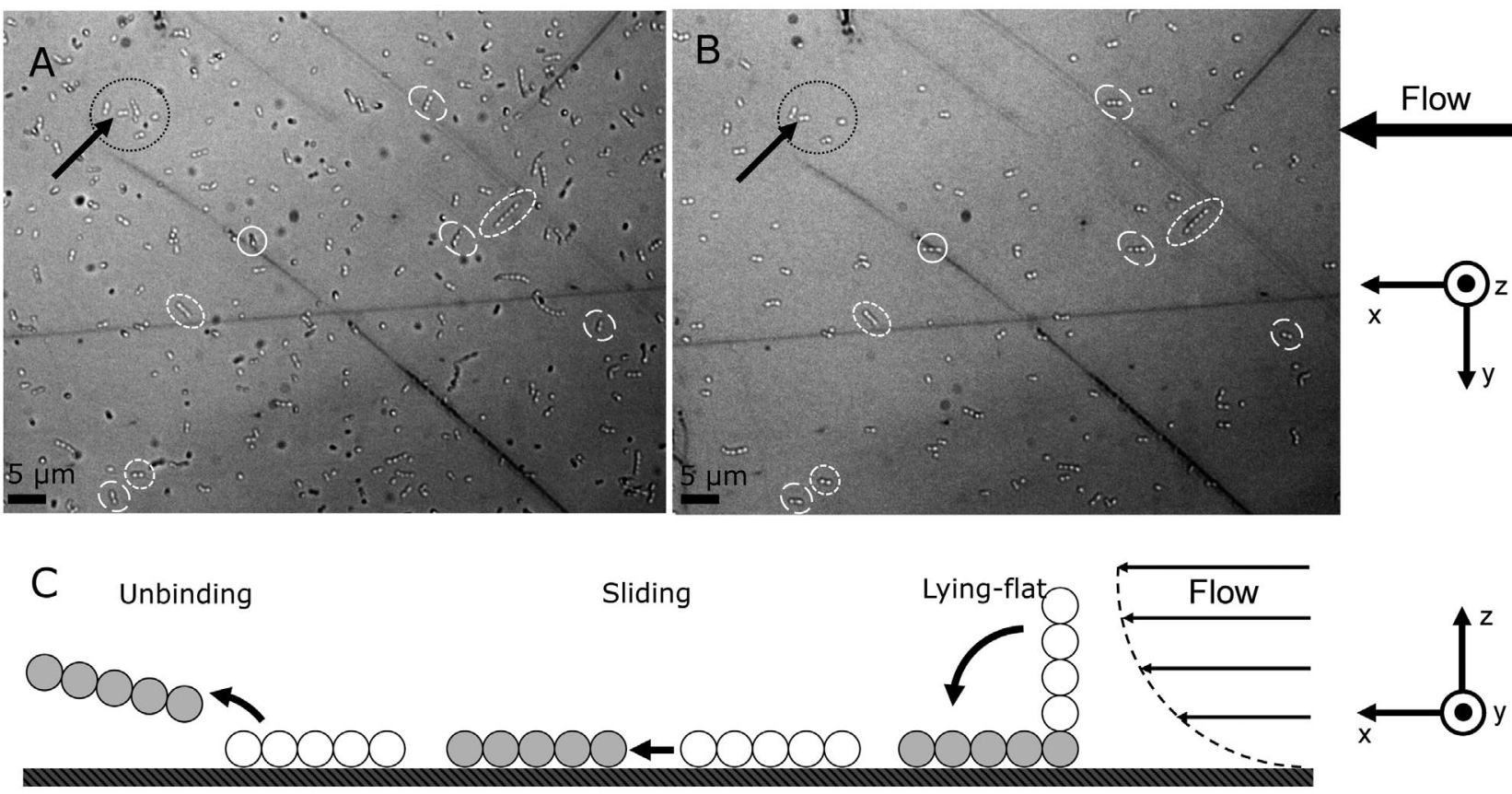

Figure 4. Images of L. lactis bacterial cells attached to bare polystyrene before (A) and after (B) the washing step (wall shear stress $\sim 0.01 \mathrm{~Pa}$ ). Example of L. lactis Pil ${ }^{\text {SrtC }}$ is shown. Four different types of motion can be observed for the bacteria: lying flat (white solid circle), stationary (white dashed circle), sliding (black arrow in the black dashed circle) and rotating (white four-arc circle). Flow direction was from right to left. (C) Scheme representing the different types of motion. Note that the lying-flat behavior has only been depicted for representation purpose.

was that moving cells successively rotated (lying-flat and rotating), translated (sliding) and ultimately detached. Therefore, it is hypothesized that rotation reflects cells that were about to unbind. Consequently, rotating-cell behavior was monitored in order to follow the population that was about to detach and compare it between piliated and non-piliated bacteria. This was obtained by using image analysis to evaluate the re-orientation dynamics of L. lactis lying flat on the surface, under increasing shear flow. To this end, for each image, the cell position was assessed by determining the $\alpha$ value (Figure 5A). Bacteria were classified according to their initial $\alpha$ value within nine classes in the range $0-90^{\circ}$ (steps of $10^{\circ}$ ). An a value of $0^{\circ}$ meant that the cell was completely aligned with the main flow direction. The evolution of these classes upon increasing the wall shear stress was then determined. Corresponding data for the Pil, $\mathrm{Pil}^{\triangle \mathrm{A}}, \mathrm{Pil}^{\triangle \mathrm{AAC}}$ and control strains attached to bare polystyrene are displayed in Figure 5B, 5C, 5D and 5E, respectively. Whatever the strain, at the beginning of the experiment (ie before the washing step and under zero flow conditions, $0 \mathrm{~Pa}$ ), bacterial cells were randomly distributed over the surface in terms of orientation, as demonstrated by the uniform distribution of the population in the different $\alpha$-angle classes. After flow initiation and shear stress increase, cells tended to re-orientate to the main flow direction (ie the fraction of the population having an $\alpha$-value in the class $0-10^{\circ}$ increased), although to an extent depending on the strain under study. For the control strain, a significant proportion of cells re-orientated toward the flow direction (Figure 5E). Furthermore, the degree of alignment increased monotonically with shear stress, especially up to $10 \mathrm{~Pa}$. Above this value, the population distribution remained fairly unchanged and could be associated with a stabilization in cell detachment as observed above (Figure 3). For the $\mathrm{Pi}^{\Delta \mathrm{AAC}}$ strain, roughly the same type of profile was obtained (Figure 5D). The Pil and $\mathrm{Pil}^{\triangle \mathrm{A}}$ strains exhibited distinct re-orientation dynamics (Figure 5B and 5C) as the distribution of the cell population within the $\alpha$-angle classes remained unchanged over the entire range of wall shear stress, ie no significant re-orientation occurred, especially for the pili-displaying strain (Pil) (Figure 5B). This is to be correlated to the low cell detachment of these strains (Figure $3 \mathrm{~A}$ ). The orientation of $\mathrm{Pil}^{\triangle \mathrm{B}}$ and $\mathrm{Pil}^{\mathrm{StrC} C^{*}}$ strains on bare polystyrene was close to that of control and $\mathrm{Pil}^{\triangle \mathrm{A} \Delta \mathrm{C}}$ strains (Figure S2A and $\mathrm{B}$ ). The data obtained using mucin-coated surfaces showed that the pili-displaying strains ( $\mathrm{Pil}$ and $\mathrm{Pil}^{\Delta \mathrm{A}}$ ) that exhibited weaker adhesion to mucin-coated surface than to bare polystyrene tended to orientate under shear flow (Figure S2C and D). This can be correlated to the adhesion properties since rotation or the lying-flat type of motion reflects a weaker number of attachment bonds and therefore a higher probability to unbind. 
(A)
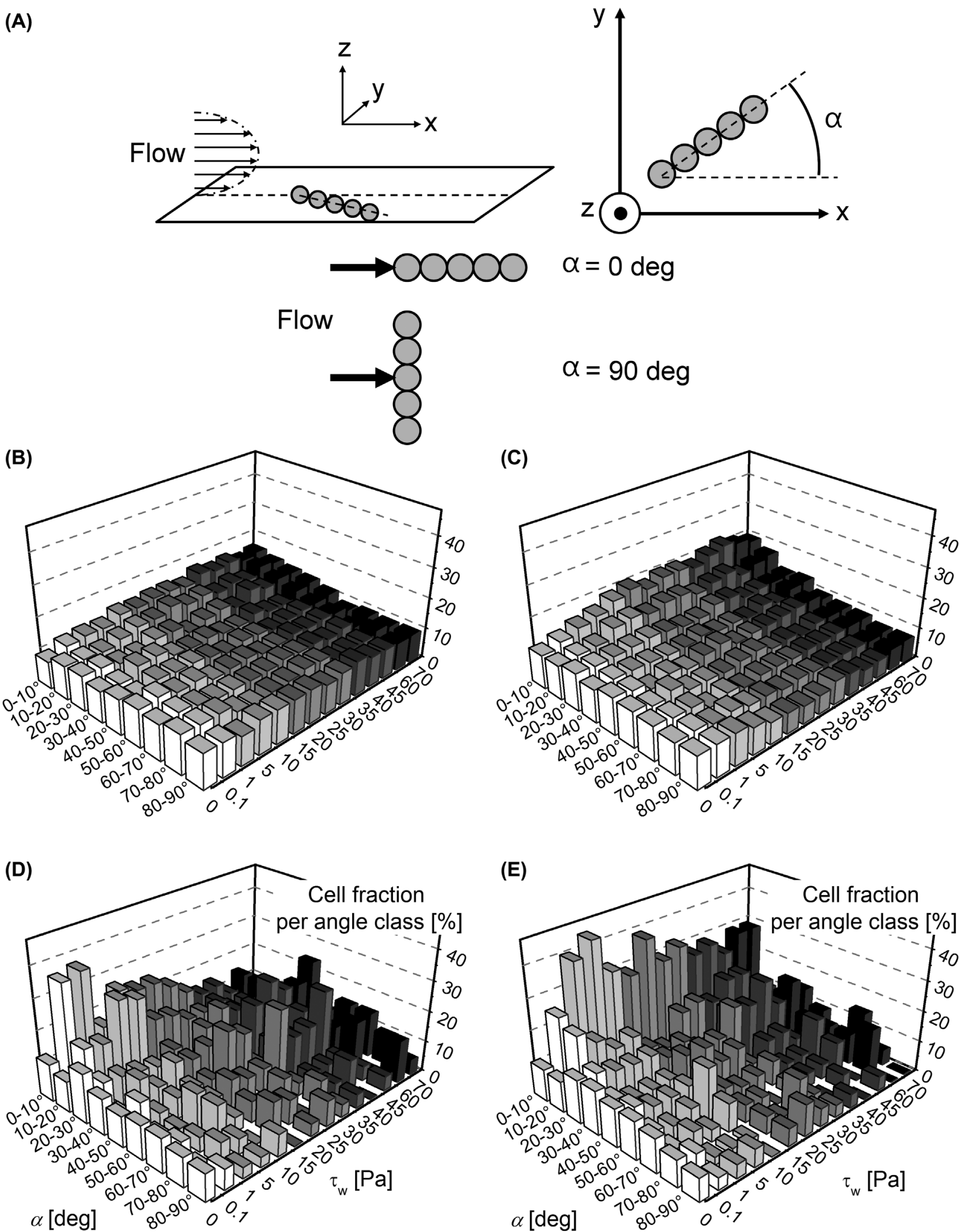

Figure 5. Cell fraction of the bacterial population attached to bare polystyrene per orientation angle a class vs wall shear stress $\tau_{w^{\prime}}$ (A) scheme depicting the orientation angle $a$ on the bare polystyrene surface. A value of $0^{\circ}$ for a means that the cell is completely aligned with the main flow direction. The example of an L. lactis five-cell chain is given; (B) Pil, (C) Pil ${ }^{\triangle A}$, (D) Pil ${ }^{\triangle A \Delta C}$ and (E) control. 


\section{Discussion}

This work confirms that pili are involved in the adhesion of L. lactis to solid surfaces (bare and mucin-coated polystyrene) under shear flow as suggested previously (Le et al. 2013). As shown recently, pili from L. lactis consist of polymers of three pilins covalently linked together in a head-to-tail manner ie the major PilB pilin whose polymers form the pilus backbone, the accessory anchoring PilC pilin tethering the pilus to the cell wall and the accessory PilA cap pilin located at the distal end of the pilus. In an attempt to dissect pili-driven adhesion mechanisms in L. lactis, a pili-displaying Pil strain as well as a series of isogenic derivatives producing altered versions of pili were used in adhesion assays. In adhesion to both bare polystyrene and mucin-coated polystyrene, the oligomerized PilB backbone pilin appeared as the key determinant of adhesion as both the $\mathrm{Pil}^{\Delta \mathrm{B}}$ strain, which could not produce the pilus backbone, and the $\mathrm{Pil}^{\mathrm{StrC}^{*}}$ strain, unable to polymerize pilins, failed to display any adhesion phenotype. In contrast, the PilA cap pilin did not appear to participate in adhesion as a $\mathrm{Pil}^{\triangle \mathrm{A}}$ strain unable to produce PilA showed adhesion levels similar to those of the native Pil strain, suggesting the absence of PilAmediated specific bonds between pili and mucins. As for the PilC anchoring pilin, it was logically found to be essential in the observed adhesion phenotypes as a PilC deficient derivative unable to anchor pili to the cell wall was greatly affected in its adhesive properties. In contrast to LGG (Tripathi et al. 2013) and the vegetal L. lactis TIL448 strain (Le et al. 2013), no strong pili-mucin interactions occurred, as shown by the enhanced cell detachment from the mucin-coated surface, especially for the most adhesive Pil and Pil ${ }^{\triangle \mathrm{A}}$ strains (Figure 3 ). As previously pointed out in AFM experiments (Dague et al. 2010), the 'anti-adhesive' properties of the mucin-coated surface are due to the conjunction of electrostatic, hydrophilic and steric repulsions induced by the structural and interfacial complexity of PGM. To detect putative functional domains in L. lactis pilins, a search for known binding domain such as lectin-like or von Willebrand factor was carried out using CAZy (http://www.cazy.org/) and Pfam (http://pfam.xfam.org/) and revealed that the PilA pilin, as well as the two other pilins, PilB and PilC, did not harbor carbohydrate-binding modules or lectin-type domain, in contrast to the vegetal strain L. lactis TIL448, in which lectin-like domain adhesins enhance adhesion to mucincoated surfaces (Le et al. 2013). Altogether, these results suggest that the L. lactis pili are engaged in non-specific adhesive processes.

In an attempt to probe such non-specific adhesive processes and based on the rationale that all experiments conducted under buffer saline conditions allowed putative electrostatic interactions to be neglected, the bacterial surface hydrophobicity was assessed in the isogenic $L$. lactis strains investigated using the MATS method. This revealed that the backbone PilB pilin was the pilus component that enhanced the bacterial cell surface hydrophobicity. Interestingly, the hydrophobicity level as measured by the MATS method was higher in strain $\mathrm{Pil}^{\mathrm{SrCC}^{*}}$ that displayed PilB monomers at its surface than in the Pil strain that displayed polymerized PilB (Table 2). This is possibly due to the MATS method that gives access to the cell surface hydrophobicity and that could neglect hydrophobicity driven by protruding elongated structures such as pili. A hydrophobic cluster analysis (Woodcock et al. 1992; Callebaut et al. 1997) on the protein sequence of PilB backbone pilin confirmed the presence of hydrophobic patches along the sequence (Figure 1). This suggests that PilB confers to the bacterium its hydrophobic character, driving strong adhesion to hydrophobic bare polystyrene and weak adhesion to the hydrophilic mucin-coated surface.

Despite numerous studies on the link between microbial adhesion and controlled hydrodynamics in dedicated laminar flow chambers (Thomas et al. 2004; Nejadnik et al. 2008; Rangel et al. 2013), the precise role of shear stress on individual adhering bacteria remains only partially understood to date. Binding of bacterial cells has notably been shown to involve four types of surface attachment behavior (rotating, laterally moving, fixed, and detaching) (Tran et al. 2011). Here, consistent with these findings, some typical types of L. lactis/solid surface attachment behavior were identified (Figure 4) as (1) lying flat on the substratum, (2) sliding, (3) fixed, or (4) rotating around a single anchoring point and spinning around that point until alignment with the flow direction was reached. Using computational fluid dynamics, Boulbene et al. (2012) demonstrated, from a theoretical point of view, that bacteria remaining attached to the surface at high shear rates should preferentially be lying flat and orientated in the flow direction, so as to minimize the drag force and torque exerted on individual cells. Such predicted mechanisms have been experimentally confirmed for Gram-negative bacteria, including Xylella fastidiosa (De La Fuente et al. 2007), P. aeruginosa (Lecuyer et al. 2011) and E. coli (Mercier-Bonin et al. 2012). Here, a substantial fraction of the lying-flat L. lactis bacteria rotated with higher wall shear stress until they aligned with the main flow direction. The re-orientation behavior was closely related to the strain under study. In particular, for piliated Pil and $\mathrm{Pil}^{\triangle \mathrm{A}}$ strains, cell re-orientation was strongly reduced compared to their non-piliated counterparts ( $\mathrm{Pil}{ }^{\triangle \mathrm{A} \Delta \mathrm{C}}$ and control strains). This is consistent with the study of Shen et al. (2012) showing that $P$. aeruginosa strains devoid of functional pili were more likely to align 
with the flow direction. This demonstrates that the presence of pili tended to impede flow-induced rotation and did not allow any rotation. In spite of this, the detachability of cells decreased substantially with the presence of pili, suggesting that oligomerized PilB (firmly attached to the cell wall through PilC) helped the bacterial cells to withstand the shear flow.

In conclusion, this work dissected the adhesive properties of piliated L. lactis on hydrophobic abiotic and biotic mucin-coated surfaces using a mechanicalstimulus-based method, namely a flow-based assay, on a panel of mutant strains differently impaired in pilus biogenesis and functionality. The respective roles of the cap, anchoring and backbone pilins were established. Different surface-associated subpopulations were characterized under shear flow (stationary, lying flat, laterally moving and rotating bacterial cells) with, for the last mentioned cells, a contribution closely related to the presence of pili as anchoring sites. These findings are of crucial importance for a better understanding of the mechanisms by which piliated Gram-positive bacteria adhere to both abiotic and biotic surfaces and then withstand shear flow. Such advanced knowledge on the pili-mediated interaction of L. lactis with those surfaces will undoubtedly pave the way for implementing novel strategies in the exploitation of lactococci in biomedical (delivery of health-promoting molecules) and food issues. In the latter, L. lactis have been proposed as candidates for bioprotective biofilms able to prevent or hamper the settlement of unwanted bacteria on biotic and abiotic surfaces in the food chain (Piard \& Briandet 2015).

\section{Author contributions}

MC, MPD, VO, MCB, PL, JCP and MMB designed the research; MC and MPD performed the research; MC, MPD, PS and MMB contributed to analytic tools and analyzed data; MC, PS, JCP and MMB wrote the manuscript.

\section{Acknowledgements}

The authors are grateful to Christophe Ellero and Nathalie Clergerie for their technical assistance in image processing and electrophoretic mobility experiments. They thank the Research Federation FERMaT (Toulouse, France) for providing access to the Morphologi device, and Luc Fillaudeau for technical assistance and helpful discussions. Finally, they are grateful to Isabelle André for fruitful discussion about the HCA predicting tool.

\section{Disclosure statement}

No potential conflict of interest was reported by the authors.

\section{ORCID}

Mickaël Castelain (D) http://orcid.org/0000-0002-0256-7663

Jean-Christophe Piard (iD http://orcid.org/0000-0002-4155-

8460

Muriel Mercier-Bonin (D) http://orcid.org/0000-0001-8398-

2529

\section{References}

Arumugam M, Raes J, Pelletier E, Le Paslier D, Yamada T, Mende DR, Fernandes GR, Tap J, Bruls T, Batto JM, et al. 2011. Enterotypes of the human gut microbiome. Nature. 473:174-180. doi:http://dx.doi.org/10.1038/nature09944

Beaussart A, Baker AE, Kuchma SL, El-Kirat-Chatel S, O’Toole GA, Dufrêne YF. 2014. Nanoscale adhesion forces of Pseudomonas aeruginosa type IV Pili. ACS Nano. 8:1072310733. doi:http://dx.doi.org/10.1021/nn5044383

Bellon-Fontaine MN, Rault J, van Oss CJ. 1996. Microbial adhesion to solvents: a novel method to determine the electron-donor/electron-acceptor or Lewis acid-base properties of microbial cells. Colloids Surf B. 7/31/;7:47-53. doi:http://dx.doi.org/10.1016/0927-7765(96)01272-6

Boulbene B, Morchain J, Bonin MM, Janel S, Lafont F, Schmitz P. 2012. A combined computational fluid dynamics (CFD) and experimental approach to quantify the adhesion force of bacterial cells attached to a plane surface. AIChE J. 58:36143624. doi:http://dx.doi.org/10.1002/aic.13747

Callebaut I, Labesse G, Durand P, Poupon A, Canard L, Chomilier J, Henrissat B, Mornon JP. 1997. Deciphering protein sequence information through hydrophobic cluster analysis (HCA): current status and perspectives. Cell Mol Life Sci. 53:621-645. doi:http://dx.doi.org/10.1007/ s000180050082

Castelain M, Duviau MP, Canette A, Schmitz P, Loubière P, Cocaign-Bousquet M, Piard JC, Mercier-Bonin M. 2016. The nanomechanical properties of Lactococcus lactis Pili are conditioned by the polymerized backbone pilin. PLOS ONE. 11:e0152053. doi:http://dx.doi.org/10.1371/journal. pone. 0152053

Cavanagh D, Fitzgerald GF, McAuliffe O. 2015. From field to fermentation: the origins of Lactococcus lactis and its domestication to the dairy environment. Food Microbiol. 47:45-61. doi:http://dx.doi.org/10.1016/j.fm.2014.11.001

Craig L, Pique ME, Tainer JA. 2004. Type IV pilus structure and bacterial pathogenicity. Nat Rev Microbiol. 2:363-378. doi:http://dx.doi.org/10.1038/nrmicro885

Dague E, Le DT, Zanna S, Marcus P, Loubière P, Mercier-Bonin M. 2010. Probing in vitro interactions between Lactococcus lactis and mucins using AFM. Langmuir. 26:11010-11017. doi:http://dx.doi.org/10.1021/la101862n

Daniel C, Poiret S, Dennin V, Boutillier D, Pot B. 2013. Bioluminescence imaging study of spatial and temporal persistence of Lactobacillus plantarum and Lactococcus lactis in living mice. Appl Environ Microbiol. 79:1086-1094. doi:http://dx.doi.org/10.1128/AEM.03221-12

Danne C, Dramsi S. 2012. Pili of gram-positive bacteria: roles in host colonization. Res Microbiol. 163:645-658. doi:http:// dx.doi.org/10.1016/j.resmic.2012.10.012

De La Fuente L, Montanes E, Meng Y, Li Y, Burr TJ, Hoch HC, Wu M. 2007. Assessing adhesion forces of type I and type IV pili of Xylella fastidiosa bacteria by use of a microfluidic flow 
chamber. Appl Environ Microbiol. 73:2690-2696. doi:http:// dx.doi.org/10.1128/AEM.02649-06

Dieye Y, Hoekman AJ, Clier F, Juillard V, Boot HJ, Piard JC. 2003. Ability of Lactococcus lactis to export viral capsid antigens: a crucial step for development of live vaccines. Appl Environ Microbiol. 69:7281-7288. doi:http://dx.doi. org/10.1128/AEM.69.12.7281-7288.2003

Drouault S, Corthier G, Ehrlich SD, Renault P. 1999. Survival, physiology, and lysis of Lactococcus lactis in the digestive tract. Appl Environ Microbiol. 65:4881-4886.

Giaouris E, Chapot-Chartier MP, Briandet R. 2009. Surface physicochemical analysis of natural Lactococcus lactis strains reveals the existence of hydrophobic and low charged strains with altered adhesive properties. Int J Food Microbiol. 131:29. doi:http://dx.doi.org/10.1016/j.ijfoodmicro.2008.09.006

Hendrickx AP, Budzik JM, Oh SY, Schneewind O. 2011. Architects at the bacterial surface - sortases and the assembly of pili with isopeptide bonds. Nat Rev Microbiol. 9:166-176. doi:http://dx.doi.org/10.1038/nrmicro2520

Hong PY, Croix JA, Greenberg E, Gaskins HR, Mackie RI. 2011. Pyrosequencing-based analysis of the mucosal microbiota in healthy individuals reveals ubiquitous bacterial groups and micro-heterogeneity. PLOS ONE. 6:e25042. doi:http:// dx.doi.org/10.1371/journal.pone.0025042

Kankainen M, Paulin L, Tynkkynen S, von Ossowski I, Reunanen J, Partanen P, Satokari R, Vesterlund S, Hendrickx AP, Lebeer S, et al. 2009. Comparative genomic analysis of Lactobacillus rhamnosus GG reveals pili containing a human- mucus binding protein. Proc Natl Acad Sci U S A. 106:17193-17198. doi:http://dx.doi.org/10.1073/ pnas.0908876106

Kline KA, Dodson KW, Caparon MG, Hultgren SJ. 2010. A tale of two pili: assembly and function of pili in bacteria. Trends Microbiol. 18:224-232. doi:http://dx.doi.org/10.1016/j. tim.2010.03.002

Lakshminarayanan B, Guinane CM, O’Connor PM, Coakley M, Hill C, Stanton C, O’Toole PW, Ross RP. 2013. Isolation and characterization of bacteriocin-producing bacteria from the intestinal microbiota of elderly Irish subjects. J Appl Microbiol. 114:886-898. doi:http://dx.doi.org/10.1111/ jam. 12085

Le DT, Tran TL, Duviau MP, Meyrand M, Guérardel Y, Castelain M, Loubière P, Chapot-Chartier MP, Dague E, Mercier-Bonin M. 2013. Unraveling the role of surface mucus-binding protein and pili in muco-adhesion of Lactococcus lactis. PLOS ONE. 8:e79850. doi:http://dx.doi. org/10.1371/journal.pone.0079850

Lebeer S, Vanderleyden J, De Keersmaecker SC. 2008. Genes and molecules of lactobacilli supporting probiotic action. Microbiol Mol Biol Rev. 72:728-64. doi:http://dx.doi. org/10.1128/MMBR.00017-08

LeBlanc JG, Burgess C, Sesma F, de Giori GS, van Sinderen D. 2005. Lactococcus lactis is capable of improving the riboflavine status in deficient rats. Br J Nutr. 94:262-267. doi:http://dx.doi.org/10.1079/BJN20051473

Lecuyer S, Rusconi R, Shen Y, Forsyth A, Vlamakis H, Kolter R, Stone HA. 2011. Shear stress increases the residence time of adhesion of Pseudomonas aeruginosa. Biophys J. 100:341350. doi:http://dx.doi.org/10.1016/j.bpj.2010.11.078

Li J, Zhang W, Wang C, Yu Q, Dai R, Pei X. 2012. Lactococcus lactis expressing food-grade beta-galactosidase alleviates lactose intolerance symptoms in post-weaning Balb/c mice. Appl Microbiol Biotechnol. 96:1499-1506. doi:http://dx.doi. org/10.1007/s00253-012-3977-4

Mann E, Schmitz-Esser S, Zebeli Q, Wagner M, Ritzmann M, Metzler-Zebeli BU. 2014. Mucosa-associated bacterial microbiome of the gastrointestinal tract of weaned pigs and dynamics linked to dietary calcium-phosphorus. PLOS ONE. 9:e86950. doi:http://dx.doi.org/10.1371/journal. pone. 0086950

Mercier-Bonin M, Dehouche A, Morchain J, Schmitz P. 2011. Orientation and detachment dynamics of Bacillus spores from stainless steel under controlled shear flow: modelling of the adhesion force. Int J Food Microbiol. 146:182-191. doi:http://dx.doi.org/10.1016/j.ijfoodmicro.2011.02.025

Mercier-Bonin M, Duviau MP, Ellero C, Lebleu N, Raynaud P, Despax B, Schmitz P. 2012. Dynamics of detachment of Escherichia coli from plasma-mediated coatings under shear flow. Biofouling. 28:881-894. doi:http://dx.doi.org/10.1080/ 08927014.2012.719160

Motta JP, Bermúdez-Humarán LG, Deraison C, Martin L, Rolland C, Rousset P, Boue J, Dietrich G, Chapman K, Kharrat $\mathrm{P}$ et al. 2012. Food-grade bacteria expressing elafin protect against inflammation and restore colon homeostasis. Sci Transl Med. 4:158ra144:158ra144. doi:http://dx.doi. org/10.1126/scitranslmed.3004212.

Nejadnik MR, van der Mei HC, Busscher HJ, Norde W. 2008. Determination of the shear force at the balance between bacterial attachment and detachment in weak-adherence systems, using a flow displacement chamber. Appl Environ Microbiol. 74:916-919. doi:http://dx.doi.org/10.1128/ AEM.01557-07

Oxaran V, Ledue-Clier F, Dieye Y, Herry JM, Péchoux C, Meylheuc T, Briandet R, Juillard V, Piard JC. 2012. Pilus biogenesis in Lactococcus lactis: molecular characterization and role in aggregation and biofilm formation. PLOS ONE. 7:e50989. doi:http://dx.doi.org/10.1371/journal. pone.0050989

Piard J-C, Briandet R. 2015. Lactic acid bacteria biofilms. biotechnology of lactic acid bacteria. Ltd: John Wiley \& Sons; p. 341-361.

Rangel DE, Marín-Medina N, Castro JE, González-Mancera A, Forero-Shelton M. 2013. Observation of bacterial type I pili extension and contraction under fluid flow. PLOS ONE. 8:e65563. doi:http://dx.doi.org/10.1371/journal. pone. 0065563

Reunanen J, von Ossowski I, Hendrickx AP, Palva A, de Vos WM. 2012. Characterization of the SpaCBA pilus fibers in the probiotic Lactobacillus rhamnosus GG. Appl Environ Microbiol. 78:2337-2344. doi:http://dx.doi.org/10.1128/ AEM.07047-11

Shen Y, Siryaporn A, Lecuyer S, Gitai Z, Stone HA. 2012. Flow directs surface-attached bacteria to twitch upstream. Biophys J. 103:146-151. doi:http://dx.doi.org/10.1016/j. bpj.2012.05.045

Steidler L, Hans W, Schotte L, Neirynck S, Obermeier F, Falk W, Fiers W, Remaut E. 2000. Treatment of murine colitis by Lactococcus lactis secreting interleukin-10. Science. 289:1352-1355. doi:http://dx.doi.org/10.1126/ science.289.5483.1352

Sullan RM, Beaussart A, Tripathi P, Derclaye S, El-Kirat-Chatel S, Li JK, Schneider YJ, Vanderleyden J, Lebeer S, Dufrêne 
YF. 2014. Single-cell force spectroscopy of pili-mediated adhesion. Nanoscale. 6:1134-1143. doi:http://dx.doi. org/10.1039/c3nr05462d

Thomas WE, Nilsson LM, Forero M, Sokurenko EV, Vogel V. 2004. Shear-dependent 'stick-and-roll' adhesion of type 1 fimbriated Escherichia coli. Mol Microbiol. 53:1545-1557. doi:http://dx.doi.org/10.1111/j.1365-2958.2004.04226.x

Tran VB, Fleiszig SM, Evans DJ, Radke CJ. 2011. Dynamics of flagellum- and pilus-mediated association of Pseudomonas aeruginosa with contact lens surfaces. Appl Environ Microbiol. 77:3644-3652. doi:http://dx.doi.org/10.1128/AEM.02656-10

Tripathi P, Beaussart A, Alsteens D, Dupres V, Claes I, von Ossowski I, de Vos WM, Palva A, Lebeer S, Vanderleyden J, et al. 2013. Adhesion and nanomechanics of pili from the probiotic Lactobacillus rhamnosus GG. ACS Nano. 7:36853697. doi:http://dx.doi.org/10.1021/nn400705u van Oss CJ. 1994. Interfacial forces in aqueous media. Taylor \& Francis.

von Ossowski I, Reunanen J, Satokari R, Vesterlund S, Kankainen M, Huhtinen H, Tynkkynen S, Salminen S, de Vos WM, Palva A. 2010. Mucosal adhesion properties of the probiotic Lactobacillus rhamnosus GG SpaCBA and SpaFED pilin subunits. Appl Environ Microbiol. 76:2049-2057. doi:http://dx.doi.org/10.1128/AEM.01958-09

Wells J. 2011. Mucosal vaccination and therapy with genetically modified lactic acid bacteria. Annu Rev Food Sci Technol. 2:423-445. doi:http://dx.doi.org/10.1146/annurevfood-022510-133640

Woodcock S, Mornon JP, Henrissat B. 1992. Detection of secondary structure elements in proteins by hydrophobic cluster analysis. Protein Eng. 5:629-635. doi:http://dx.doi. org/10.1093/protein/5.7.629 